\title{
THE EXPERIENCES OF REMAINING NURSE TUTORS DURING THE TRANSFORMATION OF NURSING COLLEGES
}

\section{Authors:}

Ellie C. van Dyk ${ }^{1}$ Gisela H. van Rensburg ${ }^{1}$ Juanita E. Tjallinks ${ }^{1}$

\author{
Affiliations: \\ ${ }^{1}$ Department of Health \\ Studies, University of \\ South Africa, South Africa
}

Correspondence to:

Gisela H. van Rensburg

e-mail:

vrensgh@unisa.ac.za

\section{Postal address:}

Department of Health

Studies, TvW Building

7-164, PO Box 392,

University of South Africa,

Pretoria, South Africa

\section{Keywords:}

coping responses;

downsizing; last in,

first out (LIFO); nursing

colleges; transformation

\section{Dates:}

Received: 12 Sept. 2007

Accepted: 11 Aug. 2009

Published: 19 Oct. 2009

How to cite this article: Van Dyk, E.C., Van

Rensburg, G.H. \&

Tjallinks, J.E., 2009, 'The

experiences of remaining nurse tutors during the

transformation of nursing colleges', Health SA

Gesondheid 14(1), Art. \#487,

9 pages. DOI: $10.4102 /$

hsag.v14i1.487

This article is available at:

http://www.hsag.co.za

(c) 2009. The Authors.

Licensee: OpenJournals Publishing. This work

is licensed under the

Creative Commons

Attribution License.

\section{ABSTRACT}

The transformation of public services and education in South Africa is part of the political and socioeconomic transition to democracy. Changes are occurring in every field, including that of the health services. A qualitative study was undertaken to investigate the experiences of the remaining nurse tutors at a school of nursing during the transformation of nursing colleges and the downsizing of staff. The study on which this article is based was aimed at describing the experiences of those individuals undergoing changes in their work environment, with the purpose of contributing to recommendations regarding the 'survival' of transformation and the downsizing of the workplace. Three themes emerged by way of the narrative descriptions and unstructured in-depth interviews conducted during the study. The first theme, revolving around affective responses, relates to the emotions, low morale, depressive moods and anxiety caused by the transformation and downsizing. The second theme, relating to the cognitive and perceptual view of transformation, revealed the thoughts, beliefs, and opinions of the remaining nurse tutors regarding the change. The perceptions of, and opinions about how, nursing education and human dignity have been affected by this transformation were also expressed. The third theme consists of the coping responses made by the nurse tutors in the form of work-related personal and social adjustments to the transformation of the nursing colleges. The maintenance of ongoing communication and participation by the nurse tutors, as part of their counselling process, is advised.

\section{OPSOMMING}

Die transformasie van die openbare dienste en onderwys in Suid-Afrika vorm deel van die politieke en sosio-ekonomiese oorgang tot demokrasie. Veranderinge vind plaas op elke terrein, wat ook gesondheidsdienste insluit. 'n Kwalitatiewe studie is onderneem om die belewing van die oorblywende verpleegdosente verbonde aan ' $n$ verplegingskool te ondersoek te midde van die transformasie van verpleegkolleges en personeelvermindering wat plaasvind. Diestudie het beoog om die belewing van indiwidue gedurende veranderinge by hul werksomgewing te beskryf, met die doel om by te dra tot aanbevelings wat personeel sou kon help om transformasie en personeelvermindering by die werkplek te 'oorleef'. Drie temas het uit die narratiewe beskrywings en ongestruktureerde in-diepte onderhoude na vore gekom. Die eerste tema, affektiewe response, sluit in emosies, lae moraal, depressiewe gemoed en angs wat deur transformasie en personeelvermindering veroorsaak word. Die tweede tema, kognitiewe en perseptuele betekenis, toon die gedagtes, oortuigings en menings van oorblywende verpleegdosente rakende die transformasie en personeelvermindering aan. Persepsies en opinies van hoe verpleegonderrig en menslike waardigheid geraak is, is ook weergegee. Die derde tema toon die hanteringsresponse, wat werkverwante, persoonlike en sosiale aanpassings van verpleegdosente gedurende die transformasie van verpleegkolleges beskryf. Daar word aanbeveel dat goeie kommunikasie en deelname in die berading van verpleegdosente gehandhaaf word.

\section{INTRODUCTION}

South Africa is currently undergoing transformation constitutionally, socially and economically. Change is taking place in many fields, including those of legislation, health, education, and law and order. Several institutions have changed from their former organisational structures, in order to adopt a new image. Such change has resulted in the restructuring of the government-run nursing colleges throughout South Africa (Reitz 1999), with a consequent involuntary staff reduction and a relocation of nurse tutors from one site to another. The rationale behind the abolition of certain posts was given as the facilitation of an integrated, equitable and efficient health system (Albertse \& Hilder 1999). The downsizing and relocation of supernumerary staff was implemented in terms of the 'last in, first out' (LIFO) principle. The total number of years spent in service, as well as the application of the latter principle, or considerations of seniority, in the public service, determined whether or not particular staff members would be absorbed into the new establishment (South African Department of Health 1999).

Transformation is a traumatic process, with downsizing threatening the very foundation on which the survivors' careers was built. As employment provides social status, when such employment is disrupted, the result is often lower status for the individual concerned. Such change increases the degree of employee stress experienced, which, in turn, increases feelings of anxiety and the frequency of depressive moods (Hamilton-Attwell 1997). Booth and Smith (1995) contend that downsizing is unpleasant for both the organisation and the employees concerned. Lawson and Angle (1998:290) describe organisational changes as 'trigger events', which serve to initiate cognitive shifts and stir up feelings and emotions that elicit reactions towards the changes concerned.

After a process of transformation, the role played by the survivors is key to determining the future success of the goals of the downsized organisation. An analysis of the impact of the changes on the remaining nurse tutors, as well as of their experiences of such changes, can serve as the basis on which to make recommendations as to the means by which the survival of, and positive outcomes for the remaining staff can be assured. Such an analysis could be of significance in the planning and implementation of future changes in the workplace. 
Brockner's (1988) conceptual model describes the reactions of survivors to the laying off of co-workers. Firstly, such layoffs have the potential to cause a variety of psychological reactions, including feelings of job insecurity, positive inequity, anger, and relief. Secondly, the psychological state of the survivors might affect their work behaviours and attitudes. Thirdly, the following moderator variables have an impact on the survivors: the nature of the work that they have to do; the individual differences of the survivors; the procedures followed by, and the programmes conducted in, the formal organisation; the security levels in the informal organisation; and the prevailing environmental conditions.

In a study conducted by Moolman and Van Wyk (1997), the negative effect of change on the employees studied was evident in its detraction from the degree of loyalty expressed towards the organisation, as well as in the levels of morale, productivity, quality of work, turnover and absenteeism from work experienced by the employees concerned. The researchers found that an emphasis is often placed on the business, rather than on the human, side of transformation. Organisations need to learn about how to manage the experiences of employees to ensure a secure work environment and employee loyalty.

Gandolfi (2008), emphasising the significant role that the survivors of downsizing play in an organisation, maintains that they either facilitate or impede the outcomes of the change process. Much attention must, therefore, be paid to the survivors if the organisation wishes to downsize successfully. The managers concerned must make sure that the employees are able to access counselling, support, help and retraining, which should be provided in a timely, honest and unbiased manner.

\section{Key concepts}

'Transformation' consists of a second-order, planned and radical change made in order to develop in a new direction. In order to succeed in transformation, a high level of commitment to the desired change is required, as well as a readiness to break with the existing mindset by means of developing new perceptions and insight (Wiesner \& Vermeulen 1996).

'Downsizing' can be defined as a 'conscious use of permanent personnel reductions in an attempt to improve efficiency and/ or effectiveness' (Wilkinson 2004:2). Such a reduction of the workforce places demands upon the organisation, workgroups, and individual employees, and requires coping and adaptation Smith, Wright and Huo (2008) describe downsizing as a retrenchment strategy, while Freeman (1999) describes it as the planned elimination, or the intentional reduction in the number, of positions or jobs, excluding those positions that are vacated due to their incumbents either retiring or resigning. In the current article, the term 'downsizing' is used to refer to the reduction in the number of staff.

In the context of downsizing, a 'remainder' (otherwise known as a 'survivor') is an employee who was neither laid off nor redeployed, and who remains in the organisation after involuntary reduction has taken place (Noer 1993). In the current article, the term 'remainder' is used to refer to those who were absorbed into the staff establishment of the nursing college.

'Coping responses' are both the covert and the overt behaviours employed by a person to alleviate and remove stress or threat. Such behaviours can either be emotion-focused, entailing the use of strategies for dealing with emotional distress and negative feelings, or problem-focused, entailing the use of strategies for managing a stressful situation (Terry \& Callan 2000).

The 'LIFO approach' is based on the employee's level of seniority, in terms of their length of service with the organisation. Such an approach can be taken in order to downsize the number of staff during the transformation of an organisation.

\section{Problem statement}

When a person survives a significant loss, psychological reactions of grief, mourning and bereavement are experienced. The feelings of loss associated with organisational change and transformation usually lead to a number of sequential emotional states. In order to resolve their grief, a person has to work through the sequence (Grunberg, Anderson-Connolly \& Greenberg 2000).

During the 1990s, the existing fragmented state administration was transformed into a new national public service. The transformation of organisational structures brought about the closing of some nursing colleges and the conversion of others. When a new provincial school of nursing was established, the previous staffing system for the provincial nursing college was abolished. In the case of the province under consideration in this study, the three campuses of the nursing college were spread throughout the province. Consequently, their merger into a single campus resulted in the relocation of staff, as well as involuntary staff reduction or the downsizing in the number of nurse tutors. After offering early retirement and voluntary resignation as ways in which to reduce the existing number of staff, the LIFO principle was adopted as a downsizing tool. Apart from their feelings of relief at retaining their posts, those surviving nurse tutors who were absorbed into the new schoo of nursing also suffered from layoff survivor sickness, in terms of which they experienced symptoms of anger, depression, fear, distrust and guilt. Layoff survivor sickness is known to have a negative impact on several different aspects of organisational behaviour, such as on the degree of loyalty felt to an organisation; the degree of morale experienced before, during and after the implementation of change; the level of productivity; the quality of work; the amount of staff turnover in the organisation; the rate of absenteeism; and whether or not there is an increase in the number of grievances relating to the organisation concerned.

The remaining nurse tutors, who were responsible for the teaching and mentoring of future professional nurses, might have experienced such changes adversely, if they had construed such changes as being implemented with lack of consideration for those involved. Such experiences are bound to have an adverse effect on future professional behaviour and role modelling. In order to address the need for effective support, it is therefore necessary to understand the nature of the experiences involved. The question therefore arose as to how the remaining nurse tutors experienced the transformation and downsizing process during the establishment of the new school of nursing.

\section{Purpose of the study}

The purpose of the study described in this article was to explore and describe the experiences of the remaining nurse tutors during the transformation and downsizing process. The results of the study were intended to contribute to the making of recommendations as how best to 'survive' such changes, in order to secure positive outcomes for the remaining staff and institution.

\section{Research objectives}

The research objectives of the study described in the current article were to explore the remaining nurse tutors' experiences regarding the downsizing and to make recommendations regarding the support of staff during the transformation and downsizing.

\section{RESEARCH DESIGN AND METHOD}

The descriptive qualitative research design chosen for the study described in this article was of a contextual and explorative nature. The study entailed collecting and analysing subjective narrative data, as well as identifying the characteristics and the significance of the human experiences involved.

Holloway (2005) describes the importance of reflexivity throughout a qualitative research project. Bracketing and intuiting were done prior to the collection of the raw data, as well as continuously throughout the study, in order to enable 
the focus to be placed on the participants' experiences. Intuiting entails the researcher remaining open to the meaning which is attributed to a phenomenon by those who have experienced it (Latimer 2003). Although a pre-exercise does not usually form part of qualitative research, unstructured interviews were conducted with three individuals who were not part of the study in order to provide the researcher with practical experience ahead of the research project. The experience empowered the researcher with the required reflexivity, bracketing and intuiting skills, so that she was able to approach the participants openly and with a clear mind. Consequently, she was able to respond in an empathic way to their individual experiences of the downsizing process.

Streubert Speziale and Carpenter (2007) explain that, during bracketing, it is necessary explicitly to expose certain assumptions, beliefs and biases. Green and Thorogood (2006) recommend that the researcher should describe her personal journey of discovery, which will serve to highlight her own values. The current researcher, therefore, wrote a narrative essay about how she herself had experienced the transformation of the colleges and the downsizing of the staff complement. Writing such an essay allowed her to set her own experiences aside, so that she was able to adopt an open and objective approach to the interviewing of the participants and the analysis of the findings. In line with the requirement of intuiting, the researcher was able to view the participants' experiences of downsizing openly and to avoid being influenced by her personal experience, which might otherwise have led to bias in her analysis.

\section{Population and sampling}

The study population comprised those remaining nurse tutors who were absorbed into the staff complement of the new school of nursing. A non-probability, purposive sampling method was used to select those participants who were information-rich for the study. The eligibility criteria for inclusion in the study were that the participants had still to be in the employ of the new school of nursing as nurse tutors, had to have formed part of the transformation and downsizing process, and had to have been appropriately absorbed into the staff complement of the new school of nursing. The participants in the study all gave their informed consent to participating in the study prior to being interviewed (Streubert Speziale \& Carpenter 2007). The size of the sample was determined when the saturation level was reached, with no new insights being generated from the data (Holloway 2005; Streubert Speziale \& Carpenter 2007). The sample size was a total of six participants, of whom four were English-speaking and two Afrikaans-speaking. They had all been in public service for between 20 and 40 years each, and the average age was between 40 and 60 years. Two individuals who were asked to participate in the study declined to take part.

\section{Data collection}

The data collection strategies employed took the two-pronged form of a narrative description in an essay format, and open-ended unstructured in-depth interviews, which were accompanied by the taking of field notes. The adoption of such an approach provided the participants with the opportunity to explain their experience of the downsizing concerned. The interviews were conducted face-to-face, in a comfortable environment. The methods of reflexivity, bracketing and intuiting were continuously used to prevent researcher bias (Holloway 2005; Latimer 2003). The interviews started with the asking of a broad, open-ended question, followed by probing questions, depending on the response received to the initial broad question.

\section{Data analysis}

Data analysis was started immediately upon receipt of the first narrative essay, as well as on completion of the first unstructured interview and field notes. Tesch (1990:115-123) describes the methods of 'de-contextualising' and 're-contextualising' for use in interpretative/descriptive analysis. Such methods form part of the three steps used to analyse the data (Tesch 1990), with step one consisting of segmenting, step two of developing an organising system, and step three of sorting the data (coding).

\section{Measures to ensure trustworthiness}

The goal of all qualitative studies is to represent the participants' experiences accurately. In order to ensure the trustworthiness of the study described in this article, Lincoln and Guba's (1984) four strategies of credibility, dependability, confirmability and transferability, as described by Streubert Speziale and Carpenter (2007), were implemented. The credibility of the study was secured by means of prolonged engagement with the study, as well as the development of a trust relationship with the informants concerned. In an attempt to ensure the objectivity of the study, the researcher wrote a narrative essay in which she described, and by means of which she was able to set aside, her personal experiences with downsizing. Peer debriefing was provided by the study supervisors, who also served as external checks for the analysed data. Member checks with participants were conducted in order to confirm the correctness of the analysis in regard to their experiences. Before commencing with the interviews, the researcher conducted a pre-exercise to refine and improve her interviewing technique. To ensure structural coherence, the Afrikaans interviews were initially transcribed into Afrikaans. After the analysis, the meaning units, themes, categories and subcategories were translated into English and edited, so as to ensure a correct rendering of the original meaning. Transferability was ensured in that the participants were representative of the different language groups and cultures concerned. A dense description of the participants' experiences was presented to provide rigour and to ensure that the findings could be transferable to other situations. Both the narrative essays and unstructured in-depth interviews were used to check the consistency of the data collected from each participant. Confirmability was secured by means of ensuring the presence of credibility, transferability and dependability throughout the study.

\section{Ethical considerations}

Due to the sensitive nature of the study discussed in this article, the possible risks were continuously examined to increase sensitivity to the participants and to avoid exposing them to undue stress. Ethical considerations were implemented to prevent ethical dilemmas, with care being taken to ensure that the rights of all the participants were accorded the due respect. The study was conducted in accordance with the three ethical principles, namely beneficence, respect for human dignity and justice, described in the Belmont Report (Polit \& Beck 2008). Throughout the study, the researcher was sensitive to the principle of allowing no harm to occur to the participants concerned. The participants were assured that they were free to withdraw at any stage, should they choose to do so. The right to self-determination and full disclosure was adhered to in respect of all the participants, in that the informed consent of each was obtained regarding their participation in the study. Their right to fair treatment and privacy was assured throughout the study. The anonymity and confidentiality of information was upheld, with all written narrative scripts and audiotapes being safely stored.

\section{DISCUSSION}

Three themes emerged from the narrative essays written by, and unstructured in-depth interviews conducted with, the participants: affective responses; cognitive and perceptual views; and coping responses. The affective responses regarded the emotions and feelings of the participants. Material relating to the cognitive and perceptual theme described the perception and beliefs expressed regarding the process. Finally, the description of the coping responses included an overview of the behavioural and adjustment responses exhibited by the participants during the study. Each theme was split up into various categories and subcategories. The categories and themes were interrelated, with 
TABLE 1

Data description

\begin{tabular}{|c|c|}
\hline THEMES & CATEGORIES \\
\hline \multirow[t]{8}{*}{ Affective responses } & $\begin{array}{l}\text { Denial of possible changes and disillusion with } \\
\text { the realisation thereof }\end{array}$ \\
\hline & Uncertainty during the process \\
\hline & Anxiety during the process \\
\hline & Anger and frustration with the changes \\
\hline & Powerlessness with a loss of control \\
\hline & Feelings of relief, pity and guilt \\
\hline & $\begin{array}{l}\text { Distrust towards the organisation and betrayal } \\
\text { by the system }\end{array}$ \\
\hline & Low morale and depressive mood \\
\hline \multirow[t]{7}{*}{ Cognitive and perceptual views } & Perception of the downsizing \\
\hline & Optimism \\
\hline & Professional image of nursing \\
\hline & Strained interpersonal relationships \\
\hline & Loss of the known environment \\
\hline & Effect on human dignity \\
\hline & Communication during the change \\
\hline \multirow[t]{4}{*}{ Coping responses } & $\begin{array}{l}\text { Motivation, loyalty and productivity during } \\
\text { transformation }\end{array}$ \\
\hline & Withdrawal behaviour \\
\hline & Need for adequate supportive systems \\
\hline & Adjustments after the change \\
\hline
\end{tabular}

some being antecedent to, or the consequences of, the others. Each meaning unit was coded (for example, one was assigned the coding G24) in reference to the initial context to which the meaning unit belonged. Afrikaans meaning units were translated into English and checked for structural coherence on the completion of the analysis. Table 1 depicts the themes and categories that emerged from the data.

\section{Theme One: Affective responses}

The affective responses of the participants in the study were evident in the expression of their feelings and emotions. They also exhibited low morale, depressive moods and anxiety about the downsizing.

\section{Denial of, and disillusionment with, the process of change}

When the transformation started, the participants reported that the changes that it would bring about seemed to be unrealistic, resulting in their thinking that such change would not actually happen. Thinking about such change made them feel uncomfortable. However, the feeling was suppressed, due to the number of rumours about transformation, which were in general circulation for some time. When the implementation of such change became imminent, the participants in the study reported experiencing disillusionment, and being shocked that it had happened. As one participant remarked:

'The moment of truth came unexpectedly. ... Where will I go? ... It seemed far-fetched.'

In a study by Suderman (1995), employees at a hospital that was closing down reported experiencing grief and going through the same psychological stages as terminally ill patients went through.

\section{Feelings of uncertainty during the process}

Feelings of uncertainty were strongly verbalised in all the interviews conducted for this study. Uncertainty about the change, which was felt once the actual transformation started, was experienced throughout the different stages of the transformation of the colleges. Another future downsizing was deemed possible, which caused feelings of persistent uncertainty among the nurse tutors. Such feelings were expressed by one of the participants as follows:

'I still felt that I was going to be out... I was not going to be absorbed ... that I would have to go and look for alternatives. Because I knew that I had not so many years, compared to most people that I know.

Werth (1994) found that such uncertainty can continue, even after downsizing has taken place, and that feelings of not having control over one's future are commonly experienced under such circumstances.

\section{Feelings of anxiety experienced during the process}

The feelings of uncertainty experienced by the nurse tutors led to their being anxious about the unknown, which might explain the strong correlation between the uncertainty and anxiety categories. The transformation, which was perceived as threatening by the participants in the study, caused much psychological stress, as can be seen in the following words of one of the participants concerned:

'It was a terrible experience ... which caused enormous stress.

There was this panic that got into us.

According to Hamilton-Attwell (1997), separation anxiety can be provoked by the announcement that employees are leaving the employ of an organisation. With employment providing social status, a break in such employment often means that the individual concerned has to accept a lower status. Such a break, therefore, induces stress, which increases the feelings of anxiety and the number of depressive moods experienced by the individual.

\section{Feelings of anger and frustration in response to the changes}

The participants in the study stated that they experienced anger due to their unhappiness about the change, about the way in which they were treated and about the insensitive way in which the downsizing was handled. One of the participants remarked:

'Anger was the most important thing I experienced'

Anger about the perceived threat of an involuntary job loss might result from fear of the permanent loss of an important feature of the job, such as status and autonomy. The participants expressed their dissatisfaction with the way in which the transformation was implemented, as well as their feelings of anger, resentment and frustration towards the organisation. Luthans and Sommer (1999) emphasise that feelings of anger and dissatisfaction form part of the five stages of grief.

Feelings of powerlessness, which are associated with a sense of loss of control

The participants reported feeling powerless when they felt that they no longer could control their own future. Such feelings of vulnerability increased when they were unsuccessful in their applications for other posts. Young and Brown (1998) found that experiences of losses have to be handled with sensitivity to prevent harm or the development of a feeling of powerlessness. Those who are threatened with job loss need both peer support and social support at work and home if their sense of psychological well-being is to be maintained (Straussner \& Phillips 1999).

\section{The interrelated nature of feelings of relief, pity and guilt}

The emotions of relief, pity and guilt were found to be interrelated in the study. Those who were to be absorbed into the staff complement expressed conflicting feelings of relief and guilt regarding the application of the LIFO criteria. One participant commented:

'You felt a bit guilty that you remain and they had to go. Because I was first in ... it was a matter of survival of the fittest now but I still feel the bitterness.'

The participants also experienced pity for those who were not to be absorbed, as well as guilt for being among those who were retained. Such experiences typify the feelings of survivor response, as explored by Suderman's 1995 study. 
Feelings of distrust towards the organisation as a whole, as well as of betrayal by the system

The participants verbalised the feelings of distrust and betrayal that they had towards top management, as well as their suspicions regarding the possibility that they might still have to face yet another downsizing. One participant remarked:

'The people I most distrust are the Human Resource Department. Our management continuously assured us that we won't [sic] lose our job, but there was always the fear that they gave us false reassurance.

Their trust in both the organisation and the system was clearly eroded, with their doubting the information that they received. When it is felt that the management is withholding information, the employees tend to feel distrustful and betrayed. Suderman (1995) found that when employees survive a layoff, they first tend to feel relieved, but sorry for the victims, with feelings of guilt developing later.

\section{Experiences of low morale and depressive moods}

Morale, loyalty and productivity were found to be strongly related. Low morale and depressive moods were evident in the participants' family relations, work motivation and productivity. Such findings were in accordance with those of Cartwright and Cooper (1997), who found that work-related changes tend to have negative family repercussions. Feelings of job insecurity also seriously tend to affect the levels of loyalty experienced by employees, as well as their level of commitment towards the employer organisation. While some employees have a continuing sense of commitment to the organisation in such instances, they may experience a lack of reciprocal commitment from the organisation itself. Noer (1993) found that some employees, under such circumstances, might remain loyal to their job and the specific business unit in which they work, but not to the overall organisation.

\section{Theme Two: Cognitive and perceptual views}

The second theme, relating to the cognitive and perceptual views of the participants involved in the study, included the way in which they perceived the process, in terms of their thoughts, beliefs and opinions regarding the organisation's use of the LIFO criteria and communication channels, as well as the impact of such use on the professional image of nursing. Their perceptions of loss and levels of optimism experienced during the process were also given due consideration.

\section{Perceptions of downsizing}

The participants in the study described in this article articulated their perceptions of the unfairness of the downsizing process. They differed in their views of how the process should have been implemented. One of the participants reported feeling that the LIFO criteria had been the safest way in which to pursue the downsizing exercise. Grunberg et al. (2000) found that layoffs, in general, tend to be perceived as being unfair, so that they usually have a negative effect on the remaining staff's levels of commitment and performance.

\section{Levels of optimism experienced}

Feelings of optimism were expressed regarding the downsizing. According to the literature relating to downsizing, such feelings are not uncommon under the circumstances. Mishra and Spreitzer (1998) explain that optimism is a hopeful response, which includes constructive and active behaviour. Participation in the process encourages the adoption of a positive approach towards downsizing. Such participation, which decreases the extent of attendant feelings of guilt and depression, is of key importance to the motivation, enthusiasm and adjustment of the participants concerned (Terry \& Callan 2000).

\section{The professional image of nursing}

Strong opinions about the professional image of nursing were expressed during the study. Some participants remarked that the professional image of nursing had been negatively affected. Participants expressed their concern about the loss of experts and skilled tutors in specialised areas, who might, if they had been retained, have played a valuable role in the development of nursing education, as well as in the enhancement of the professional image of nursing as a whole. As one participant said,

'The college lost very valuable people from whom they could benefit. They have lost people who know the nursing field and they have a lot of skills.'

The loss of such skills might cause nursing education to suffer for a long time to come. The participants' perceptions were consistent with those that were reported in other studies regarding the consequences following on the loss of highly skilled employees during downsizing exercises in the past (Mariner Tomey 2004; Yoder-Wise 2007)

\section{Strained interpersonal relationships}

Family, including marital, relationships and friendships were negatively affected due to the stress brought about by the downsizing. Participants described their feelings of animosity and non-verbal negativity, which they had felt on the announcement of which staff members were to be retained. Those who were not confronted by antagonism described the loss of friendships and supportive relationships. According to Kets de Vries and Balazs (1997), in cases of downsizing the remaining group may tend to exclude those who have to leave the organisation from their companionship, leading to the staff complement splitting into two: the retained and the departing.

\section{Loss of the known environment}

The nurse tutors experienced the loss of their known environment, due to the merging of the colleges and their own relocation from one site to another. Being forced to relocate at relatively short notice caused them much anxiety. One of the participants described their existing environment as consisting of 'cherished and loved' areas. Another participant complained of being 'physically ignored'. Grunberg et al. (2000) found that experiences of loss are common during transformation, with those affected by such transformation experiencing loss of the bonds formed by attachment and affiliation.

Violation of the right to the respect of human dignity According to the remaining nurse tutors, the way in which they were treated undermined their feelings of human dignity, because the entire staff complement was treated insensitively. They reported finding the reassignment of the workload humiliating. The derogatory remarks made by certain nurse tutors who left the college caused much offence to those who remained. Mariner Tomey (2004 states that the undermining of a person's human dignity can result in reduced productivity levels as well as low morale, as a result of the person's self-esteem being threatened. Wilkinson (2004) concluded that, because work provides social status and prestige to the employee, if the employee is threatened with its loss, the parameters that one sets for oneself might be severely adversely affected.

\section{Communication during the change}

Communication seemed to be an important aspect for the participants in the study. The aspect included the nurse tutors' perception of the information received during the process, as well as their attitude concerning the need for them to participate in the process. The need for honest information without false assurance and a strong need for clear and correct information emerged. The participants perceived the amount of information that they had received from top management as inadequate. However, they felt that they had received enough information from middle management. Despite their feeling that the amount of information from this tier of management had been sufficient, they still felt that certain information with which they had been provided had portrayed a false impression. They expressed the 
need for true and honest participation throughout the entire process, instead of which they thought that there had been too little participation and no opportunity for them to contribute to any decision-making. The results of a study undertaken by Casey, Miller and Johnson (1997) revealed that downsizing appeared to heighten the perception of information deprivation and altered information-seeking patterns at work.

\section{Theme Three: Coping responses}

The third theme, on coping responses, indicated how the participants had coped with the threat and possibility of change. The findings regarding this theme described the work-related, personal and social adjustments that the participants had to make in terms of the new organisation.

\section{The degree of motivation, loyalty and productivity experienced during the transformation}

The participants stated that they had lacked motivation and had felt that, due to the job insecurity that they were required to face, there had been no need for them to take any new risks in the work environment. Their levels of motivation and productivity, accordingly, had decreased. Some of the questions that they had asked themselves were: 'Why should I go on?'; 'Where are we going to?'; and 'What will happen to us?' In general, the way in which transformation and downsizing are implemented tends to affects the survivors' perceptions and attitudes. Grunberg et al. (2000) concluded that when downsizing is considered to have taken place unfairly, the resultant levels of commitment and performance are reduced. The degree of motivation, loyalty and productivity experienced during the transformation also affects the overall morale experienced within the organisation as a whole.

\section{Withdrawal behaviour}

The consequences of the amount of anxiety and stress experienced ranged from physical symptoms to individual withdrawal and increased rates of absenteeism. The absenteeism rate of the participants increased due to the stress, psychosomatic illnesses and depression that they experienced. The impact of such stress on the participants' health was consistent with findings from other studies that described increases in the rate of absence from the workplace as well as in the amount of longterm sick leave taken as a result of downsizing (Moolman \& Van Wyk 1997). The incidence of withdrawal and negative behaviour, such as absenteeism and a high employee turnover, tends to increase when layoffs are perceived as being unfair. Ill health, psychosomatic illnesses and depression tend to increase the levels of absenteeism among those employees who are retained. Unproductive behaviour, as well as threats of job loss, insecurity and negative feelings, may cause employees to withdraw or to leave an organisation for more secure job opportunities (Luthans \& Sommer 1999).

More severe feelings of withdrawal were expressed as the need to quit the system during the downsizing process. Experiences of dissatisfaction with the way in which the changes were implemented increased the perceived need to leave the system voluntarily to move to jobs that seemed to offer more job security. Some participants also mentioned that they were prepared to quit if they had to face another downsizing. Luthans and Sommer (1999) state that, in stressful work situations, there is a strong propensity to withdraw from the environment and to keep one's eye open for other job possibilities.

\section{The need for adequate support systems}

The period during which the downsizing took place had been found to be stressful, with the participants experiencing the need for support, but feeling that they had had to cope on their own. They had felt that they had needed to support their remaining colleagues, as well as the redeployed nurse tutors. The support that was provided within groups was found to be insufficient.
One participant complained:

'There is a tendency of neglecting us ... they think we don't need support, because people might think we are knowledgeable. We sort of supported each other.'

Professional support, which should have been provided on an individual basis, was lacking. The support received from middle management was generally regarded as having been adequate, but that from top management was found to be inadequate. Straussner and Phillips (1999) found that, during change, it was extremely important to have support from one's peer group, family and partners.

\section{Adjustments made after a change}

The adjustments that participants had to make, in terms of the merging of the two colleges and the relocation of employees, included that they had to commute daily for quite long distances, and had to rearrange their housekeeping. The merging of the colleges had also led to the redesign and redistribution of the existing workload among the remaining tutors. Such change had included having to adjust to the use of another language, as well as to unfamiliar content and new responsibilities. Such findings correlate with those made in Rosenberg's (1999) study. He concluded that those employees who were retained had to work harder and often had to do overtime with no compensation, which led to stress, decline in the quality of work performed, unhappiness and burnout.

Interpersonal adjustments included the development of new relationships and friendships following the merger of the two colleges. The remaining nurse tutors suddenly had to get to know one another, and had to build new working relationships across cultures. They made comments such as:

'Friends have left ... we have to take the place of their loved ones. How would the people handle us?'

Crouter and Manke's (1994) study highlights the importance of having friendships at work, and indicates that friendship may have both positive and negative consequences regarding work stress and the amount of social support that is received in the workplace.

\section{FINDINGS}

When they took place, transformation and downsizing were regarded as posing threats to the remaining nurse tutors. Brockner's (1988) conceptual model was found to be applicable in terms of the event. The process, which was experienced as threatening, served to elicit certain psychological states and the emotions of the participants (the remaining nurse tutors), which affected the outcomes of their responses. Affective experiences of anxiety, depression and emotions were found to have occurred. Such findings accord with Mishra and Spreitzer's (1998) typology of survivors' responses on the destructive and passive dimension, which leads to the conclusion that the participants mainly experienced fearful responses, amounting to feelings of being the 'walking wounded'. Such experiences affected the nurse tutors holistically and had a severe impact on their personal, professional and working life. Ultimately, their motivation, loyalty and productivity were affected.

Three of the five stages of bereavement, namely denial, anger and depression, as propounded by Kübler-Ross (as quoted in Mariner Tomey 2004) were found to have been experienced. As the change seemed to be unreal, it was initially denied. The insensitive way in which the authorities dealt with the situation may have elicited anger from the participants. Feelings of worthlessness with regard to the situation rebounded on the family relationships of the tutors, as well as on their levels of work motivation and productivity, resulting in depressive moods. The stages of bargaining and acceptance were not clearly evident in the work situation, possibly due to the feelings of powerlessness that were experienced by the nurse tutors at the time. No opportunity was provided for bargaining in the form of 
effective participation and communication. Experiencing all of the stages of bereavement is important because, if the final stage of acceptance is not reached, the process may result in negative consequences for both the participants and the organisation concerned.

In such circumstances, the fear of subjectivity should be minimised. In order to minimise such fear, the length of service, or LIFO, should be regarded as offering the best criterion for downsizing (Luthans \& Sommer 1999). The participants perceived the LIFO criterion employed by the organisation in different ways. Although verbalised as being the safest criterion, the way in which the criterion was employed was regarded as unfair. The individual differences of the nurse tutors, such as their degree of self-esteem, morale, anxiety levels and motivation, may have affected their perceptions and experiences. Downsizing should, thus, be undertaken in such a way that it is perceived as taking place fairly. Such a perception of fairness can only be possible when the stakeholders involved have an opportunity to participate fully in effective bargaining about the situation.

Concerns regarding the ongoing credibility of the professional image of the nurse were expressed, due to the loss of skilled tutors resulting from resignations, and the acceptance of packages and involuntary redeployment. Such concerns are important in regard to the maintenance of nursing education standards. The loss of skilled professionals may, in future, affect the operational requirements of the institution. In a nursing college, there must be a sufficient number of skilled and professionally qualified tutors to teach all the relevant nursing disciplines. If the staff are relatively unmotivated, the standard of continuous education and professional development may be adversely affected. A negative work environment detracts from the employability, rather than from the career aspirations, of the employees concerned with upward mobility within organisations. Employees are less willing to take risks in their work environment, due to a lack of motivation and an impairment of their performance (YoderWise 2007).

When an employee faces a situation of job insecurity, the resulting tension leads to insecurity about his or her family's economic, educational and social future. The spouse then tends to find it increasingly difficult to be supportive (Yoder-Wise 2007).

The perception of the loss of interpersonal relationships, of the known and beloved working environment, and of human dignity tends to bring about feelings of loss of attachment, identity, esteem, support, credibility and reputation. Such feelings echo the experiences described in Kübler-Ross's (1969) theory of bereavement. Information provided by management in the transformation and downsizing of the colleges was perceived to be ineffective during certain stages of the change. Such inadequacies serve to emphasise the importance of communication, as well as the need both for information without false assurance and for participation in the process (Mariner Tomey 2004). Successful transformation depends largely on the maintenance of an effective communication process (HamiltonAttwell 1997). Information given to the survivors affects their ability to respond perceptively, to seek information about the situation, to engage in spreading rumours and to encourage resistance. Communication can help to heal those who have to deal with a traumatic experience, by restoring an element of trust. Consequently, such communication may have an effect on the work performance of the remaining nurse tutors.

In the current situation, communication, which is preferably face to face, should take place without delay. Rumours stem from collective insecurity, and can have serious negative consequences (Cartwright \& Cooper 1997). Yoder-Wise (2007) maintains that survivors often try to cope with change in ways that are neither organisationally productive nor personally healthy. They often have an unquenchable thirst for information from the formal channels, such as the media, as well as by way of rumours and non-verbal messages. Above all, they tend especially to seek justification and explanation from the managers concerned. Thus, the need for genuine, non-contradictory communication, without hidden agendas, enhances the credibility of management and can serve as an effective antidote to rumours (Noer 1993).

The coping and adjustment patterns of the participants indicate an emotion-focused, rather than a problem-focused, response. The coping response of 'layoff survivor sickness', as described by Noer (1993), was evident, with symptoms of anger, depression, fear, distrust, and guilt. Such a sickness could negatively affect the remaining nurse tutors and lead to a further decrease in their levels of productivity and performance. At the time of the change, the nurse tutors experienced a decrease in their levels of motivation, loyalty and productivity. Their experiences of uncertainty and increased workload caused them to exhibit withdrawal behaviour, such as absenteeism due to the deterioration of their health, as well as feelings that they needed to quit the system. The participants expressed a need for adequate professional support, which was supplied in insufficient amounts. However, they did receive support from such informal sources as the other members of their own family and their remaining colleagues, and they were, in turn, able to provide support to their redeployed colleagues.

Overall, the findings of the study described in this article indicate the need for transformation and downsizing to be undertaken with due consideration for the human dignity of those concerned. Such consideration should be shown in the effective handling of communication and the granting of individual support to those who remain during, as well as after the implementation of, such traumatic change. The disruption of the nurse tutors' normal and predictable personal and professional way of life, ways of working, environment and interpersonal relationships should be acknowledged and addressed through debriefing and counselling, in order to help them make the necessary adjustments. By involving the employees in problem-solving and decision-making, positive outcomes such as trust, increased productivity, decreased turnover and a sense of responsibility should be achieved.

\section{STRENGTHS AND LIMITATIONS}

The findings of the study provided a comprehensive, holistic bio-psychosocial description of the affective, cognitive and coping experiences of those concerned, which did not focus on preconceived ideas in terms of certain variables. The description of the findings contribute to the literature relating to people's reactions to transformation, with the recommendations emanating there from offering the possibility of utilisation in the case of future transformation.

The nature of a qualitative study relies on the researcher's judgement regarding data collection and analysis. The researcher was responsible for collecting most of the data during the unstructured in-depth interviews, as well as for the analysis of the data. Since the researcher was one of the remaining nurse tutors, such a position might have led to undue bias. To prevent such bias, the researcher implemented the control mechanisms of reflexivity, intuiting and bracketing throughout the study. Another limitation on the study might have been that of participant effect. Since the data was collected by means of narrative descriptions and unstructured in-depth interviews, the participants may have caused bias by not revealing their experiences in depth.

\section{RECOMMENDATIONS}

It is recommended that, during any transformation, the following aspects should be considered. Communication is an important aspect of all change, and should be entered into with all those employees who are involved in the change. Relevant information should be provided at special meetings, which are held regularly. A spokesperson for both the management and the employees could facilitate such communication. Circulars should be used to inform the employees about the required 
activities and the decisions that are made. Employees need to be involved and also need to liaise with all levels of management about the change taking place. Such involvement could take the form of discussing the change with a spokesperson, or of participating in meetings, information sessions and workshops.

On an individual level, questionnaires might be used to elicit concerns and recommendations about the changes being implemented. The remaining employees should also receive emotional support by means of individual counselling, rather than in the form of group sessions, as the latter were found to be relatively ineffective.

\section{CONCLUSION}

During downsizing, both the professional qualifications of the participants and the LIFO principle should be considered. The need for experienced and skilful, suitably qualified staff is of vital importance to maintain the professional image and standards of nursing. Effective communication, participation and counselling should be implemented during the transformation and downsizing process. The implementation of such measures should serve to revitalise the remaining employees by increasing their levels of optimism and by empowering them in terms of job enrichment, increased opportunities for participation, the selfdirected nature of work teams and the allocation of rewardss.

Understanding the experiences of employees during transformation and downsizing can serve as a basis for consideration during change in the workplace to ensure employee wellness and support. Policies and procedures should be formulated in such a way that the process can be perceived as relatively smooth flowing and positive. Ultimately, change is inevitable.

\section{REFERENCES}

Abbott, P. \& Sapsford, R., 1998, Research methods for nurses and the caring professions, 2nd edn., Open University Press, Buckingham.

Albertse, M. \& Hilder, A.J., 1999, Report on: Department of Health; Human Resource Directorate; Formal Personnel Development Sub-directorate: Organisation and post establishment revision of the Free State nursing colleges, FSPA, Human Resource Development Directorate, BA/D 200.

Babbie, E. \& Mouton, J., 2001, The practice of social research, Oxford University Press, Cape Town.

Booth, R. \& Smith, T.L., 1995, 'Downsizing: Case study of a career in crises', Journal of Employment Counseling 32(3), 115131.

Brockner, J., 1988, 'The effects of work layoff on survivors: Research, theory and practice', in B.M. Staw \& L.L. Cummings (eds.), Research in Organizational Behavior, pp. 215-220, JAI Press, Greenwich.

Brockner, J., 1990, 'Scope of justice in the workplace: How survivors react to co-worker layoffs', Journal of Social Issues 46(1), 95-106.

Cartwright, S. \& Cooper, C.L., 1997, Managing workplace stress, SAGE, London.

Casey, M.K., Miller, V.D. \& Johnson, J.R., 1997, 'Survivors' information seeking following a reduction in workforce', Communication Research 24(6), 774-781.

Crouter, A.C. \& Manke, B., 1994, 'The changing American workplace: Implications for individuals and families', Family Relations 43(2), 117-124.

Freeman, S.J., 1999, 'The gestalt of organizational downsizing: Downsizing strategies as packages of change', Human Relations 52(12), 1505-1541.

Gandolfi, F., 2008, 'Learning from the past - downsizing lessons for managers', Journal of Management Research 8(1), 3-17.

Green, J. \& Thorogood, N., 2006, Qualitative methods for health research, SAGE, London.
Grunberg, L., Anderson-Connolly, R. \& Greenberg, E.S., 2000, 'Surviving layoffs: The effects on organizational commitment and job performance', Work and Occupations 27(1), 7-31

Hamilton-Attwell, A., 1997, 'The impact of transformation on employees', Management Today 13(1),18-22.

Henning, E., 2004, Finding your way in qualitative research, Van Schaik, Pretoria.

Holloway, I., 2005, Qualitative research in health care, Open University Press, Maidenhead.

Kets de Vries, M.F.R. \& Balazs, K., 1997, 'The downside of downsizing', Human Relations 50(1), 11-50.

Kübler-Ross, E., 1969, On death and dying, Macmillan, New York.

Latimer, J., 2003, Advanced qualitative research for nursing, Oxford, Blackwell Science.

Lawson,M.B.\&Angle,H.L.,1998, 'Uponreflection: Commitment, satisfaction, and regret after a corporate relocation', Group and Organization Management 23(3), 289-317.

Luthans, B.C. \& Sommer, S.M., 1999, 'The impact of downsizing on workplace attitudes: Differing reactions of managers and staff in a health care organization', Group and Organization Management 24(10), 46-70.

Marais, E.N. \& Schepers, J.M., 1996, 'The effects of organisational restructuring on job satisfaction, career aspirations and stress levels of employees', Journal of Industrial Psychology 22(3), 1-6.

Mariner Tomey, A., 2004, Guide to nursing management and leadership: Middle East and African edition, Elsevier, Beijing.

Massey, V.H., 1995, Nursing research: A study and learning tool, 2nd edn., Springhouse Corporation, Springhouse.

Mishra, A.K. \& Spreitzer, G.M., 1998, 'Explaining how survivors respond to downsizing: The roles of trust, empowerment, justice and word redesign', Academy of Management Review 23(3), 567-588.

Moolman, L. \& Van Wyk, C. de W., 1997, 'Die rol van arbeidsverhoudinge in veranderings-bestuur', Management Dynamics 6(1), 61-86.

Mullaney, S., 1997, 'The lived experience of phenomenology', in S. Thomson (ed.), Nurse Teachers as Researchers: A Reflective Approach, pp. 155-180, Arnold, London.

Nelson, B., 1998, 'The care of the un-downsized', Public Management 80(4), 20-22.

Noer, D.M., 1993, Healing the wounds: Overcoming the trauma of layoffs and revitalizing downsized organizations, Jossey-Bass, San Francisco.

Polit, D.F. \& Beck, C.T., 2008, Nursing research: Generating and assessing evidence for nursing practice, 8th edn., Lippincott, Philadelphia.

Reitz, U., 1999, 'Kolleges word een op kampus van Nico Malan', Die Burger, 10 November, p. 12

Rosenberg, S.J., 1999, 'Social work and downsizing: Theoretical implications and strategic responses', Journal of Sociology and Social Welfare 26(2), 3-19.

Smith, F., Wright, A. \& Huo, Y.P., 2008, 'Scapegoating only works if the herd is big: Downsizing, management turnover and company turnaround', International Journal of Business Strategy 8(3), 72-83.

South African Department of Health, 1999, 'Placement of staff on new staff establishment', Desk Talk Free State Health, 1, $1-2$.

Straussner, S.L.A. \& Phillips, N.K., 1999, 'The impact of job loss on professional and managerial employees and their families', Families in Society: The Journal of Contemporary Human Services 80(6), 642-648.

Streubert Speziale, H.J. \& Carpenter, D.R., 2007, Qualitative research in nursing advancing the humanistic imperative, 4th edn., Lippincott Williams \& Wilkins, Philadelphia.

Suderman, E., 1995, 'Downsizing: The implications for nursing educators in a hospital setting', Journal of Nursing Staff Development 11(1), 7-12.

Terry, D.J. \& Callan, V.J., 2000, 'Employee adjustment to an organization change: A stress and coping perspective', in P. 
Dewe, M. Leiter \& T. Cox (eds.), Coping, health and organization, pp. 259-276, Taylor \& Francis, London.

Tesch, R., 1990, Qualitative research: Analysis types and software tools, Falmer Press, New York.

Werth, R., 1994, 'Is there life after change?', Human Resource Management 10(4), 12-13.

Wiesner, R. \& Vermeulen, L.P., 1996, 'A framework for the study of paradigm change in industrial psychology', South African Journal of Economic and Management Science 20, 155-174.
Wilkinson, A., 2004, 'Downsizing, rightsizing or dumbsizing?', TQM Journal, October 2004, 1-18.

Yoder-Wise, P.S., 2007, Leading and managing in nursing, 4th edn., Elsevier, St Louis.

Young, S. \& Brown, H., 1998, 'Effects of hospital downsizing on surviving staff', Nursing Economics 16(5), 258-262. 